\title{
Postoperative developed intra-abdominal desmoid tumor after surgical resection of gastrointestinal malignancy: A review of 10 cases
}

\author{
Ahmad Sakr1,2, Jong Min Lee1, Homoud Alawfi1, Mohammed Alessa1, Nam Kyu Kim¹ \\ 'Division of Colorectal Surgery, Department of Surgery, Colorectal Cancer Clinic, Severance Hospital, Yonsei University College of Medicine, Seoul, \\ Korea; \\ ${ }^{2}$ Colorectal Surgery Unit, Department of General Surgery, Mansoura Faculty of Medicine, Mansoura University Hospital, Mansoura, Egypt
}

Purpose: Desmoid tumors are locally aggressive tumors with no known potential for metastasis. They tend to recur even after complete excision. Sometimes it is not easy to differentiate between intra-abdominal desmoid and tumor recurrence, especially after gastrointestinal (GI) tumor resection. The current study aims to review the characteristics, management, and outcomes of patients with intra-abdominal desmoid tumor post $\mathrm{Gl}$ resection.

Methods: During the period between 2007 and 2018, after a retrospective review of patients' clinical data, 10 patients were finally included. Medical records were screened for demographic, clinical, pathological data, management strategy, postoperative morbidity, mortality, recurrence rate and follow-up.

Results: The study comprised 10 patients (8 males). The median age was 53.5 years (range, 35-68 years). Two patients diagnosed as familial adenomatous polyposis (FAP). All the patients underwent previous GI resection: three (30\%) for colon cancer, three (30\%) gastrectomy, two $(20 \%)$ total proctocolectomy with ileal pouch-anal anastomosis (TPC+IPAA) for FAP, one (10\%) low anterior resection (three rectal cancers) and one (10\%) distal pancreatectomy. The tumor was found to be in bowel mesentery in eight cases (80\%). The median tumor size was 5.3 $\mathrm{cm}$ (range, $2.6-19.0 \mathrm{~cm}$ ). Six patients (60\%) underwent open resection, while four patients $(40 \%)$ underwent laparoscopic surgery. Complications occurred in five cases (50\%) and ranged from Clavien-Dindo (II-III). The median follow-up period was 16.5 months (1.5-136.0 months) with recurrence in one case (10\%). Pathology came out to be desmoid tumor fibromatosis in all cases.

Conclusion: When a mass develops after surgical resection for abdominal GI malignancy and tends to be large in size, located in the bowel mesentery and away from previous primary tumor site, most probably it is desmoid rather than tumor recurrence.

Keywords: Fibromatosis, Abdominal, Adenomatous polyposis coli, Mesentery, Neoplasm recurrence

Received: Jan 29, 2019 Revised: Jun 21, 2019 Accepted: Jun 22, 2019 Correspondence to: Nam Kyu Kim

Division of Colorectal Surgery, Department of Surgery, Yonsei University College of Medicine, 50-1 Yonsei-ro, Seodaemun-gu, Seoul 03722, Korea Tel: +82-2-2228-2100, Fax: +82-2-313-8289

E-mail: namkyuk@yuhs.ac

ORCID: Ahmad Sakr (https://orcid.org/0000-0003-0292-9086), Jong Min Lee (https://orcid.org/0000-0003-1654-1533), Homoud Alawfi (https://orcid.org/00000003-3170-5495), Mohammed Alessa (https://orcid.org/0000-0002-2716-5484), Nam Kyu Kim (https://orcid.org/0000-0003-0639-5632)

Copyright @ 2019 Korean Society of Surgical Oncology

This is an Open Access article distributed under the terms of the Creative Commons Attribution Non-Commercial License (http://creativecommons.org/licenses/by-nc/4.0) which permits unrestricted non-commercial use, distribution, and reproduction in any medium, provided the original work is properly cited.

\section{INTRODUCTION}

Desmoid tumors (fibromatosis), are rare locally aggressive tumors with less liability of metastasis. They have a high rate of recurrence even after complete excision. In patients with familial adenomatous polyposis (FAP; Gardner syndrome), desmoid tumors tend to be more aggressive and may result in vital organs destruction and can be fatal. They account for around $0.03 \%$ of all neoplasms. The incidence is $2-4$ million population per year [1]. The age of presentation is between 15 and 60 with more females' predilection [2].

Desmoid tumor occurs more frequently in FAP patients than other population with the majority of tumors being intra-abdomi- 

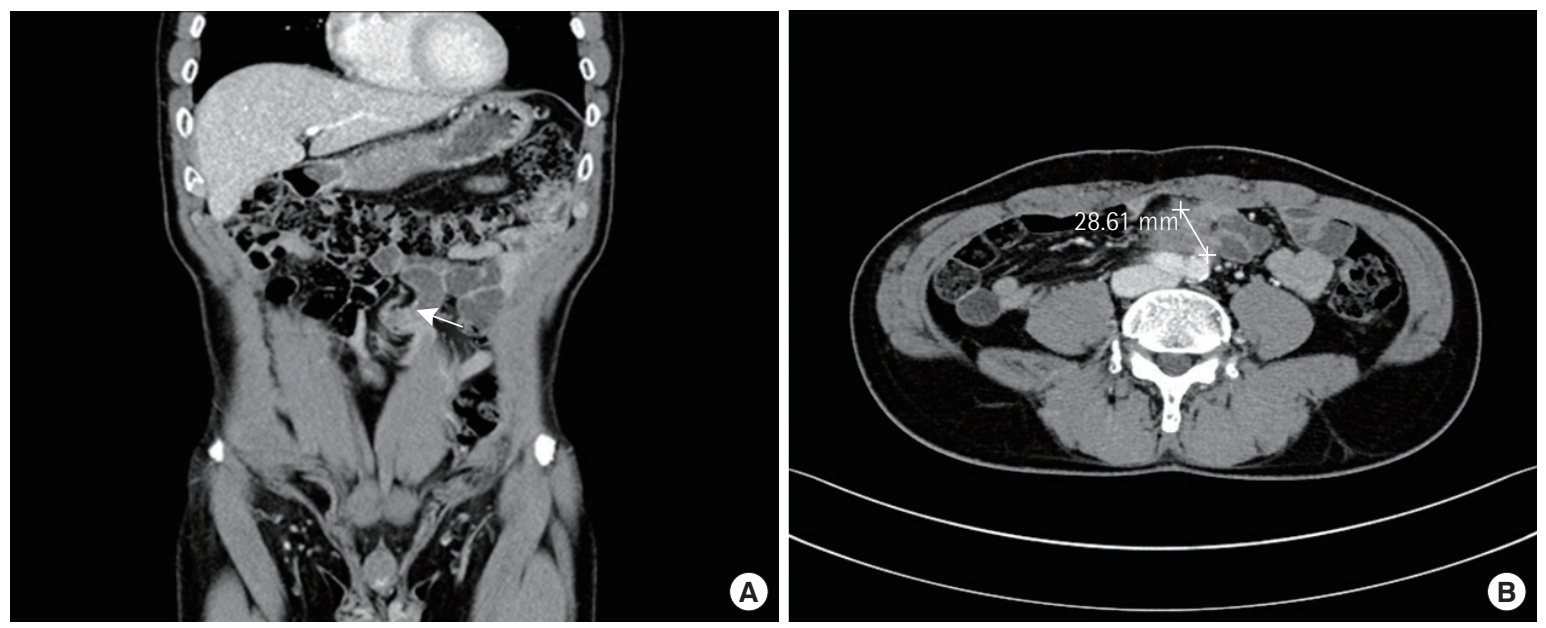

Fig. 1. (A, B) Computed tomography showing 28.61-mm mass in the bowel mesentery in a patient post right hemicolectomy for ascending colon cancer. The arrow indicates the site of the mass and its size.

nal. However, extremity desmoids can also occur [3]. Other risk factors include pregnancy, mutation of APC (adenomatous polyposis coli) gene, previous antecedent trauma and family history of a desmoid tumor $[4,5]$.

It is not easy to diagnose desmoid tumors before surgical excision through a biopsy especially if the patient has a previous history of abdominal malignancy. It may be difficult to differentiate between these lesions and disease recurrence or metastasis [6-8].

Most of known about desmoid tumor after previous abdominal malignant gastrointestinal (GI) tumors in the literature is in the form of case reports. During a routine follow-up after curative resection for GI malignancy, computed tomography (CT) and ultrasound image sometimes showed a mass in the abdominal cavity. Most of them underwent exploration of the abdominal cavity and excised for therapeutic and diagnostic purpose. Regarding this point, we need to characterize intrabdominal desmoid and need to know some clinical characteristics which help to wait and see in those patients.

\section{METHODS}

Retrospective study including 10 patients who underwent surgery for intra-abdominal desmoid tumor excision in the Department of Surgery, Severance Hospital, Yonsei University (Seoul, South Korea), between July 2007 and March 2018. The study protocol was approved by the Institutional Review Board of Yonsei University (IRB No. 4-2018-1122). Written informed consents were waived off because of being retrospective study.

All patients who underwent previous surgical excision for abdominal GI malignancy including stomach, pancreas, colorectal with or without FAP were only included. We excluded patients

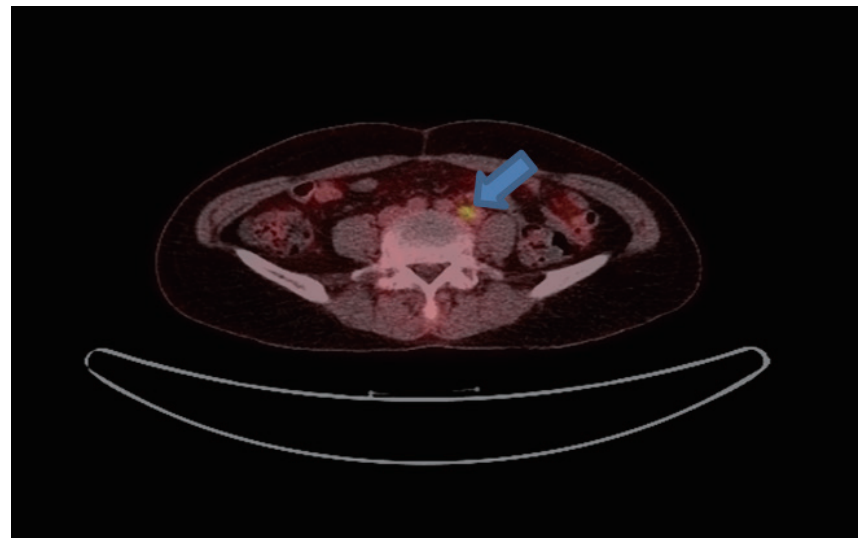

Fig. 2. Positron emission tomography-computed tomography showing mild fluorodeoxyglucose (FDG) uptake of desmoid mass (arrow) at the root of inferior mesenteric artery.

with the previous excision of benign intra-abdominal tumors, patients with extra-abdominal or abdominal wall desmoid.

We collected patients' demographic data, history and type of surgery patient received, diagnostic methods, preoperative carcinoembryonic antigen (CEA) level, operative details, postoperative complications, histopathology follow-up and recurrence rate.

All patients were suspected for recurrence during routine follow-up, the investigation was done in the form of CT scan for all cases (Fig. 1) and positron emission tomography (PET)-CT scan for three cases, CEA level (Fig. 2).

\section{RESULTS}

Ten patients were eligible for this study (Tables 1,2). The median age was 53.5 years (range, 35-68 years). Eight (80\%) were males. 
Table 1. Patients baseline characteristics

\begin{tabular}{|c|c|}
\hline Characteristic & Data \\
\hline Total no. & 10 \\
\hline Age (yr) & $53.5(35-68)$ \\
\hline \multicolumn{2}{|l|}{ Sex } \\
\hline Male & $8(80)$ \\
\hline Female & $2(20)$ \\
\hline FAP & $2(20)$ \\
\hline \multicolumn{2}{|l|}{ Previous operation } \\
\hline Gastrectomy & $3(30)$ \\
\hline Colon cancer ( 2 sigmoid, 1 ascending) & $3(30)$ \\
\hline Rectal cancer (2 TPC+IPAA, 1 LAR) & $3(30)$ \\
\hline Distal pancreatectomy & $1(10)$ \\
\hline Time interval of presentation (mo) & $26.5(2-216)$ \\
\hline \multicolumn{2}{|l|}{ Clinical presentation } \\
\hline Asymptomatic (during regular follow-up) & $6(60)$ \\
\hline Intestinal obstruction & $2(20)$ \\
\hline Abdominal mass and pain & $1(10)$ \\
\hline Accidental discovery & $1(10)$ \\
\hline \multicolumn{2}{|l|}{ Tumor site } \\
\hline Small bowel mesentery & $8(80)$ \\
\hline Inferior mesenteric artery root & $1(10)$ \\
\hline Left retroperitoneal area near splenic flexure & $1(10)$ \\
\hline Tumor size (cm) & $5.3(2.6-19.0)$ \\
\hline CEA level & $1.60(0.43-3.48)$ \\
\hline \multicolumn{2}{|l|}{ Operation method } \\
\hline Open & $6(60)$ \\
\hline Laparoscopic & $4(40)$ \\
\hline Operative time (min) & $188(55-425)$ \\
\hline Blood loss (mL) & $25(0-900)$ \\
\hline \multicolumn{2}{|l|}{ Complications } \\
\hline Fever $^{\text {a) }}$ & $2(20)$ \\
\hline Wound infection, dehiscence ${ }^{b)}$ & $1(10)$ \\
\hline lleostomy prolapse: revision ${ }^{\text {b) }}$ & $1(10)$ \\
\hline Diaphragmatic injury: repair with chest tube ${ }^{b)}$ & $1(10)$ \\
\hline Hospital stay (day) & $6(4-31)$ \\
\hline Follow-up period (mo) & $16.5(1.5-136.0)$ \\
\hline Recurrence & $1(10)$ \\
\hline Mortality & 0 \\
\hline
\end{tabular}

Data are presented as median (range) or number (\%).

FAP, familial adenomatous polyposis; TPC+IPAA, total proctocolectomy ileal pouch anal anastomosis; LAR, low anterior resection; CEA, carcinoembryonic antigen.

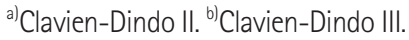

Two with a history of FAP, one male, and one female. All cases underwent previous abdominal surgery for GI malignancy.

Three patients underwent gastrectomy, two radical total and one radical subtotal gastrectomy for stomach cancer. One patient received distal pancreatectomy for pancreatic neuroendocrine tumor. Three rectal cancer two of them were post total proctocolec-

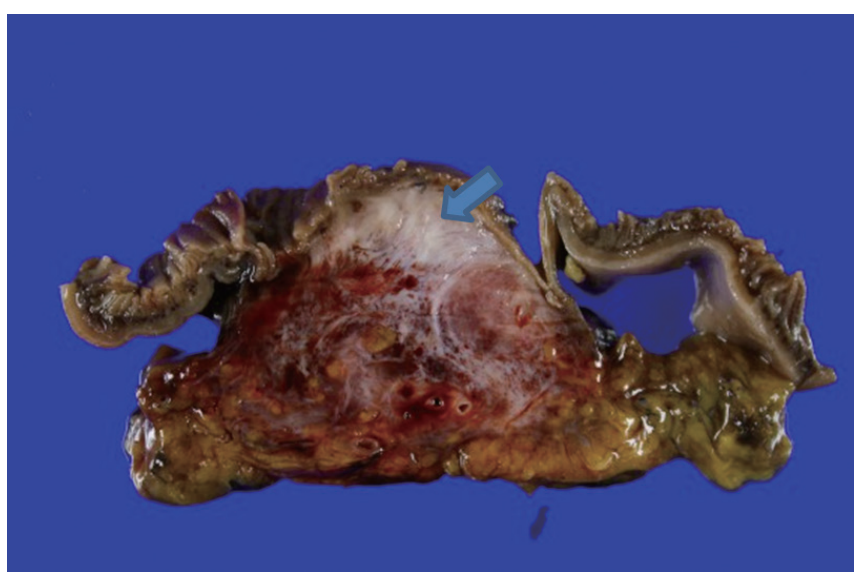

Fig. 3. Segment of resected small bowel showing desmoid whitish mass $3 \times 3.5 \mathrm{~cm}$ (arrow), relatively well delineated located within the bowel mesentery.

tomy with ileal pouch-anal anastomosis (post-TPC+IPAA) for rectal cancer on top of FAP and one low anterior resection. Three colectomies for colon cancer: two sigmoid and one ascending colon cancer.

In six patients, desmoid was asymptomatic just detected during routine follow up, while in other four patients, two patients were presented with intestinal obstruction, one with left upper quadrant huge mass around $19 \mathrm{~cm}$ and pain, while the last case, desmoid tumor was accidentally discovered in a patient presented with acute abdomen and suspected anastomotic leakage post rectal cancer on top of FAP. The median time interval of presentation desmoid tumor after previous surgery was 26.5 months (range, 2-216 months).

For the desmoid tumor, the most frequent site for it was the small bowel mesentery (Fig. 3) which was seen in eight cases, meanwhile, it was retroperitoneal near splenic flexure in one patient and near the inferior mesenteric artery root in another patient. So away from the primary tumor site. The median size of the tumor was $5.3 \mathrm{~cm}$ (range, 2.6-19.0 cm). There was no elevation of CEA level in any case and the median preoperative CEA level was 1.60 (range, $0.43-3.48$ ). No specific findings were noted in the preoperative CT scan and even the PET-CT which was done in three cases showed mild or increased uptake that why tumor recurrence could not be excluded.

Open excision of the mass was routinely used except in four patients in whom laparoscopic approach was done. The median operative time was 188 minutes (range, 55-425 minutes), while the median blood loss was $25 \mathrm{~mL}$ (range, 0-900 mL). Small bowel resection was done in six cases. Radical surgery (R0 resection) was done in all cases except in the patient who underwent radical subtotal gastrectomy so, diagnostic laparoscopic frozen biopsy of multiple masses of small bowel mesentery was done. While, for pallia- 
Table 2. Detailed patients information

\begin{tabular}{|c|c|c|c|c|c|c|c|c|c|c|c|c|}
\hline $\begin{array}{l}\text { Patient } \\
\text { no. }\end{array}$ & $\begin{array}{l}\text { Age } \\
\text { (yr) }\end{array}$ & Sex & FAP & $\begin{array}{l}\text { Previous } \\
\text { operation }\end{array}$ & $\begin{array}{l}\text { Time } \\
\text { interval } \\
\text { (mo) }\end{array}$ & $\begin{array}{c}\text { Clinical } \\
\text { presentation }\end{array}$ & $\begin{array}{l}\text { Tumor } \\
\text { site }\end{array}$ & $\begin{array}{l}\text { Tumor } \\
\text { size } \\
(\mathrm{cm})\end{array}$ & $\begin{array}{l}\text { CEA } \\
\text { level }\end{array}$ & $\begin{array}{l}\text { Risk } \\
\text { factor }\end{array}$ & Complications & Recurrence \\
\hline 1 & 49 & M & No & $\begin{array}{l}\text { Radical total } \\
\text { gastrectomy }\end{array}$ & 24 & $\begin{array}{l}\text { Asymptomatic } \\
\text { (routine follow } \\
\text { up) }\end{array}$ & $\begin{array}{l}\text { Small bowel } \\
\text { mesentery }\end{array}$ & 6.8 & 1.87 & $\begin{array}{l}\text { Previous abdominal } \\
\text { surgery }\end{array}$ & No & No \\
\hline 2 & 48 & M & No & $\begin{array}{l}\text { Radical } \\
\text { subtotal } \\
\text { gastrectomy }\end{array}$ & 18 & $\begin{array}{l}\text { Asymptomatic } \\
\text { (routine follow } \\
\text { up) }\end{array}$ & $\begin{array}{l}\text { Small bowel } \\
\text { mesentery }\end{array}$ & 2.8 & 0.43 & $\begin{array}{l}\text { Previous abdominal } \\
\text { surgery }\end{array}$ & No & No \\
\hline 3 & 56 & M & No & $\begin{array}{l}\text { Anterior } \\
\text { resection for } \\
\text { sigmoid } \\
\text { colon cancer }\end{array}$ & 18 & $\begin{array}{l}\text { Asymptomatic } \\
\text { (routine follow } \\
\text { up) }\end{array}$ & $\begin{array}{l}\text { Small bowel } \\
\text { mesentery }\end{array}$ & 13.0 & 3.46 & $\begin{array}{l}\text { Previous abdominal } \\
\text { surgery }\end{array}$ & No & Yes \\
\hline 4 & 57 & M & No & $\begin{array}{l}\text { Right } \\
\text { hemicolectomy }\end{array}$ & 216 & $\begin{array}{l}\text { Asymptomatic } \\
\text { (routine follow } \\
\text { up) }\end{array}$ & $\begin{array}{l}\text { Small bowel } \\
\text { mesentery }\end{array}$ & 3.5 & 1.54 & $\begin{array}{l}\text { Previous abdominal } \\
\text { surgery }\end{array}$ & Fever & No \\
\hline 5 & 35 & M & Yes & TPC+IPAA & 84 & $\begin{array}{l}\text { Emergency } \\
\text { (peritonitis) }\end{array}$ & $\begin{array}{l}\text { Small bowel } \\
\text { mesentery }\end{array}$ & 5.5 & 0.57 & $\begin{array}{l}\text { FAP+previous } \\
\text { abdominal } \\
\text { surgery }\end{array}$ & No & No \\
\hline 6 & 68 & M & No & $\begin{array}{l}\text { LAR for rectal } \\
\text { cancer }\end{array}$ & 2 & $\begin{array}{l}\text { Intestinal } \\
\text { obstruction }\end{array}$ & $\begin{array}{l}\text { Small bowel } \\
\text { mesentery }\end{array}$ & 5.0 & 0.92 & Previous surgery & $\begin{array}{l}\text { Wound infection } \\
\text { and dehiscence }\end{array}$ & No \\
\hline 7 & 54 & M & No & $\begin{array}{l}\text { Radical total } \\
\text { gastrectomy }\end{array}$ & 18 & $\begin{array}{l}\text { Asymptomatic } \\
\text { (routine follow } \\
\text { up) }\end{array}$ & $\begin{array}{l}\text { Small bowel } \\
\text { mesentery }\end{array}$ & 5.0 & 1.66 & $\begin{array}{l}\text { Previous abdominal } \\
\text { surgery }\end{array}$ & No & No \\
\hline 8 & 53 & M & No & $\begin{array}{l}\text { Distal } \\
\text { pancreatectomy }\end{array}$ & 30 & $\begin{array}{l}\text { Abdominal } \\
\text { mass and pain }\end{array}$ & $\begin{array}{l}\text { Left retroperitoneal } \\
\text { near splenic } \\
\text { flexure }\end{array}$ & 19.0 & 3.48 & $\begin{array}{l}\text { Previous abdominal } \\
\text { surgery }\end{array}$ & $\begin{array}{l}\text { Diaphragmatic } \\
\text { excision repair with } \\
\text { chest tube }\end{array}$ & No \\
\hline 9 & 52 & $\mathrm{~F}$ & No & $\begin{array}{l}\text { Anterior } \\
\text { resection for } \\
\text { sigmoid colon } \\
\text { cancer }\end{array}$ & 39 & $\begin{array}{l}\text { Asymptomatic } \\
\text { (routine follow } \\
\text { up) }\end{array}$ & IMA root & 2.6 & 1.68 & $\begin{array}{l}\text { Previous abdominal } \\
\text { surgery }\end{array}$ & No & No \\
\hline 10 & 58 & $\mathrm{~F}$ & Yes & TPC+IPAA & 84 & $\begin{array}{l}\text { Intestinal } \\
\text { obstruction }\end{array}$ & $\begin{array}{l}\text { Small bowel } \\
\text { mesentery }\end{array}$ & 16.0 & 1.46 & $\begin{array}{l}\text { FAP+previous } \\
\text { abdominal } \\
\text { surgery }\end{array}$ & $\begin{array}{c}\text { Fever } \\
\text { Ileostomy prolapse: } \\
\text { revision }\end{array}$ & No \\
\hline
\end{tabular}

FAP, familial adenomatous polyposis; CEA, carcinoembryonic antigen; $M$, male; F, female; TPC+IPAA, total proctocolectomy lleal pouch anal anastomosis; LAR, low anterior resection; IMA, inferior mesenteric artery.

tive aim in another patient who underwent exploration for intestinal obstruction after TPC+IPAA for rectal cancer on top of FAP.

Postoperative pathology for all cases was desmoid tumor fibromatosis which showed positive B catenin stain. As regard postoperative complication, it varies between Clavien-Dindo (II-III), in the form of postoperative fever, wound infection and dehiscence, one patient had a chest tube and diaphragmatic repair during excision of a huge tumor near the splenic flexure and one patient had ileostomy prolapse. The median length of hospital stay was 6 days (range, 4-31 days). There was no mortality. The median follow-up period was 16.4 months (range, 1.6-136.1 months), with recurrence in one case.

\section{DISCUSSION}

Desmoid tumor is a soft tissue tumor that arises in the fascia and musculoaponeurotic tissues. It is characterized by fibroblastic proliferation, intercellular space condensation of collagen fibers. Although being histologically benign, the desmoid tumor is clinically considered intermediate between a benign and a malignant tumor not only due to the lack of surrounding capsule but also because of its infiltrative growth pattern. Thus, local recurrence is common, but not distant metastasis [9].

Three types of desmoid tumors are identified according to the location which include abdominal wall type (49\%), extra-abdominal wall type (43\%), and intra-abdominal type (8\%) which is the 
least common [1].

As the preoperative diagnosis of intra-abdominal desmoid tumor is difficult with no specific characteristic imaging findings [10], so it is difficult to differentiate between desmoid and tumor recurrence particularly in patients with previous surgical resection of abdominal malignancy. The current study aimed to distinguish between desmoid tumors and tumor recurrence.

According to Belliveau and Graham [11], the mean age is $44 \pm$ 16 years and the male to female is 6 to 4 and among patients with intra-abdominal desmoid tumors. The most frequent site is the small bowel mesentery ( $72 \%$ ); of note, $45 \%$ of patients have a history of abdominal surgery and 22\% have Gardner syndrome. In comparison to these findings, our current study showed older patients with a median age of 53.5 years (range, 35-68 years), with more male predominance (male:female, $4: 1$ ). We also reported the same finding that the commonest site of the presentation was small bowel mesentery $80 \%$. All patients had previous abdominal surgery which is a risk factor for desmoid tumor development. Two female patients had a history of FAP.

Intra-abdominal desmoid tumors are often asymptomatic unless being large in size. Therefore, when presented, mostly will be in the form of an abdominal mass, followed by abdominal distension, abdominal pain, vomiting and sometimes intestinal obstruction due to mechanical compression of the tumor [12]. In our study most of the cases were asymptomatic and desmoid was accidentally discovered during routine surveillance to rule out tumor recurrence. Secondly, emergency presentation in the form of intestinal obstruction in two cases post rectal cancer surgery and peritonitis post rectal cancer on top of FAP and lastly abdominal mass.

Mesenteric masses have always been a challenge to evaluate radiologically. Ultrasound, CT, magnetic resonance imaging (MRI), and PET-CT are typically used to differentiate intra-abdominal tumors. The ultrasound appearance of the desmoid tumor is often a hypoechoic mass with internal homogeneity. On CT, a desmoid tumor usually appears as a solid mass with an essentially homogeneous density, although the degree of enhancement varies among tumors. On MRI, a desmoid tumor typically shows high signal intensity or heterogeneous signal intensity on T2-weighted images indicating a high density of cellular components, while low signal intensity indicates a low density of cellular components and corresponds to the area with abundant collagen [12]. On PET-CT, desmoid tumors tend to have low fluorodeoxyglucose (FDG) uptake, depending on the amount of cellular tissue and mitotic activity of fibromatosis [13]. In our study, CT scan cannot rule out tumor recurrence and most of the reports were in the form of soft tissue masses in the small bowel mesentery. PET-CT was done in three of our cases which showed mild uptake in one case and increased uptake in two cases.

Shin et al. [14] reported that postoperative intra-abdominal desmoid tumors can develop up to 7 years after abdominal surgery. In our current study, the range of presentation of desmoid post abdominal surgery was from 2 months up to 18 years. The reason for this discrepancy may be due to frequent surveillance after resection of malignant tumors in this study.

The behavior of abdominal desmoid tumors is often unpredictable. They can be indolent and spontaneously regress while others can be very aggressive with rapid growth and mass effect [15]. Even they do not metastasize, they may recur. Some studies quote recurrence rates up to $40 \%$ [16].

Many treatment options for abdominal desmoid tumors are addressed. Complete surgical excision with wide surgical margins (at least $1 \mathrm{~cm}$ ) is often the first line therapy for resectable tumors $[10,17]$. Most patients require an individualized treatment approach. Wait and see protocol is also accepted for asymptomatic tumors since spontaneous regression and stabilization are possible, so sometimes surgical resection is not always necessary [18]. Other treatment options other than resection, include radiation and pharmacological therapies (nonsteroidal anti-inflammatory drugs [NSAIDs], anti-estrogen drugs, molecularly targeted agents and anticancer drugs); especially in patients where the desmoid tumor is infiltrative with vital structures involvement, or margins are not free of the tumor $[19,20]$.

There are hormonal and non-hormonal options for medical management. Tamoxifen is often used in combination with NSAIDs [15,21]. Tamoxifen is a selective estrogen receptor (ER) modulator that inhibits cell proliferation by binding to ER. Alternatively, another analog named Raloxifene has been used with prior studies and proved positive results [22]. A partial or complete response can be obtained via NSAIDs. Chemotherapy is reserved for people who have aggressive nonsurgical tumors or in patients after failure of other therapy regimes. Chemotherapy should be given in doses individualized to the patient based upon a team approach. Furthermore, tyrosine kinase inhibitor may be an option for treatment in patients who are not a candidate for surgery. Finally, radiation treatment is an option, reserved mainly for extra abdominal tumors due to the risk of radiation-induced injury to intra-abdominal structures, as radiation-induced enteritis [23]. In our study and as recurrence of malignancy was suspected so surgical resection to confirm the histopathology was mandatory to avoid unnecessary systemic chemotherapy.

Though the overall prognosis of patients with desmoid tumors not associated with FAP is relatively good [24], the recurrence and mortality rates of desmoid tumor patients with FAP are $22 \%-85 \%$ and $10 \%-60 \%$, respectively [25]. Thus, an elevated risk of recur- 
Table 3. Difference between desmoid tumor and tumor recurrence

\begin{tabular}{lll}
\hline & \multicolumn{1}{c}{ Desmoid tumor } & Tumor recurrence \\
\hline CEA & Normal & High \\
Location & $\begin{array}{l}\text { Away from the primary tumor } \\
\text { site (small bowel mesentery) }\end{array}$ & $\begin{array}{l}\text { Near the primary } \\
\text { tumor site }\end{array}$ \\
Size & Larger & Small \\
Shape & Round or oval & Oval or irregular \\
FDG PET-CT & Mild uptake & Increased uptake \\
\hline
\end{tabular}

CEA, carcinoembryonic antigen; FDG, fluorodeoxyglucose; PET-CT, positron emission tomography-computed tomography.

rence should be considered even after surgery, and regular follow-up is required for early detection of recurrence.

During follow-up of patients after GI surgery with CT scan, we sometimes find intra-abdominal mass anywhere in the abdominal cavity, at that time, we must differentiate it from tumor recurrence. We found the clinical characteristics of benign desmoid tumor and it may help to predict intra-abdominal desmoid tumor after surgery for GI tract cancer. The clinical characteristics of desmoid tumors include; being large sized soft tissue oval or rounded mass with less uptake in PET-CT scan, usually located away from primary tumor resection site, not associated with CEA level elevation (Table 3) [26].

In patients with a history of surgery for intra-abdominal malignancies, it may be difficult to distinguish the tumor recurrence from the desmoid tumor. However, the possibility of desmoid tumors should be into consideration. Desmoid tumors tend to be large in size, CEA level is normal and located in the bowel mesentery and away from the previous primary tumor site.

\section{CONFLICT OF INTEREST}

No potential conflict of interest relevant to this article was reported.

\section{ACKNOWLEDGMENTS}

The authors thank the participants of the current study.

\section{REFERENCES}

1. Reitamo JJ, Hayry P, Nykyri E, Saxen E. The desmoid tumor. I. Incidence, sex-, age- and anatomical distribution in the Finnish population. Am J Clin Pathol 1982;77:665-73.

2. Mankin HJ, Hornicek FJ, Springfield DS. Extra-abdominal desmoid tumors: a report of 234 cases. J Surg Oncol 2010;102:380-4.

3. Gurbuz AK, Giardiello FM, Petersen GM, Krush AJ, Offerhaus GJ, Booker SV, et al. Desmoid tumours in familial adenomatous pol- yposis. Gut 1994;35:377-81.

4. Nieuwenhuis MH, Lefevre JH, Bulow S, Jarvinen H, Bertario L, Kerneis S, et al. Family history, surgery, and APC mutation are risk factors for desmoid tumors in familial adenomatous polyposis: an international cohort study. Dis Colon Rectum 2011;54:1229-34.

5. Schiessling S, Kihm M, Ganschow P, Kadmon G, Buchler MW, Kadmon M. Desmoid tumour biology in patients with familial adenomatous polyposis coli. Br J Surg 2013;100:694-703.

6. Goscinski MA, Hole KH, Tonne E, Ryder T, Groholt KK, Flatmark K. Fibromatosis in vertical rectus abdominis myocutaneous flap imitating tumor recurrence after surgery for locally advanced rectal cancer: case report. World J Surg Oncol 2016;14:63.

7. Mizuno R, Akiyoshi T, Kuroyanagi H, Fujimoto Y, Ueno M, Oya M, et al. Intra-abdominal desmoid tumor mimicking locoregional recurrence after colectomy in a patient with sporadic colon cancer: report of a case. Surg Today 2011;41:730-2.

8. Das S, Subhashini J, Isiah R, Kurian S. Mesenteric fibromatosis mimicking metastasis: a case report and review of literature. J Gastrointest Cancer 2012;43 Suppl 1:S73-6.

9. Hayry P, Reitamo JJ, Totterman S, Hopfner-Hallikainen D, Sivula A. The desmoid tumor. II. Analysis of factors possibly contributing to the etiology and growth behavior. Am J Clin Pathol 1982;77:67480.

10. Mizuno M, Kawaguchi Y, Kawanishi A, Kawashima Y, Maruno A, Ogawa M, et al. An intra-abdominal desmoid tumor, embedded in the pancreas, preoperatively diagnosed as an extragastric growing gastrointestinal stromal tumor. Case Rep Oncol 2017;10:301-7.

11. Belliveau P, Graham AM. Mesenteric desmoid tumor in Gardner's syndrome treated by sulindac. Dis Colon Rectum 1984;27:53-4.

12. Yamaguchi K, Hirakata R, Maeda S, Kominami T, Kitamura K. Spontaneous isolated intra-abdominal mesenteric fibromatosis. Case report. Eur J Surg 1991;157:293-6.

13. Basu S, Nair N, Banavali S. Uptake characteristics of fluorodeoxyglucose (FDG) in deep fibromatosis and abdominal desmoids: potential clinical role of FDG-PET in the management. Br J Radiol 2007;80:750-6.

14. Shih LY, Wei CK, Lin CW, Tseng CE. Postoperative retroperitoneal desmoid tumor mimics recurrent gastrointestinal stromal tumor: a case report. World J Gastroenterol 2012;18:6172-6.

15. Santos M, Rocha A, Martins V, Santos M. Desmoid tumours in familial adenomatous polyposis: review of 17 patients from a Portuguese tertiary center. J Clin Diagn Res 2016;10:PC01-5.

16. Escobar C, Munker R, Thomas JO, Li BD, Burton GV. Update on desmoid tumors. Ann Oncol 2012;23:562-9.

17. Nieuwenhuis MH, Casparie M, Mathus-Vliegen LM, Dekkers OM, Hogendoorn PC, Vasen HF. A nation-wide study comparing sporadic and familial adenomatous polyposis-related des- 
moid-type fibromatoses. Int J Cancer 2011;129:256-61.

18. Nakanishi K, Shida D, Tsukamoto S, Ochiai H, Mazaki J, Taniguchi $\mathrm{H}$, et al. Multiple rapidly growing desmoid tumors that were difficult to distinguish from recurrence of rectal cancer. World J Surg Oncol 2017;15:180.

19. Lim CL, Walker MJ, Mehta RR, Das Gupta TK. Estrogen and antiestrogen binding sites in desmoid tumors. Eur J Cancer Clin Oncol 1986;22:583-7.

20. Hansmann A, Adolph C, Vogel T, Unger A, Moeslein G. Highdose tamoxifen and sulindac as first-line treatment for desmoid tumors. Cancer 2004;100:612-20.

21. Howard JH, Pollock RE. Intra-abdominal and abdominal wall desmoid fibromatosis. Oncol Ther 2016;4:57-72.

22. Tonelli F, Ficari F, Valanzano R, Brandi ML. Treatment of desmoids and mesenteric fibromatosis in familial adenomatous polyposis with raloxifene. Tumori 2003;89:391-6.

23. Hapgood C, DeLong A. Recurrent enlarging mesenteric desmoid tumor following remote surgical resection. Case Rep Radiol 2017;2017:2312617.

24. Clark SK, Phillips RK. Desmoids in familial adenomatous polyposis. Br J Surg 1996;83:1494-504.

25. Rodriguez-Bigas MA, Mahoney MC, Karakousis CP, Petrelli NJ. Desmoid tumors in patients with familial adenomatous polyposis. Cancer 1994;74:1270-4.

26. Lee JH, Song KD, Cha DI, Hyun SH. New intra-abdominal mass after operation for colorectal cancer: desmoid tumor versus peritoneal seeding. Abdom Radiol (NY) 2018;43:2923-7. 